\title{
Local Uses and Parasitism of Loranthaceae in Sudano-Sahelian Zone of Cameroon: Case of Diamare Plain in Far North Region
}

\author{
Souare Konsala ${ }^{1}$, Baye-Niwah Claudette ${ }^{2}$, \\ Hamawa Yougouda ${ }^{3}$, Tezore Bakary Prudence ${ }^{1}$
}

\author{
${ }^{1}$ University of Maroua, Faculty of Science, Department of Biological Sciences, PO Box: 814 Maroua \\ ${ }^{2}$ University of Maroua, Higher Teacher's Training College, Department of Life and earth Sciences, Maroua \\ ${ }^{3}$ National Advanced School of Engineering of Maroua, PO Box: 46 Maroua
}

\begin{abstract}
The Loranthaceae, commonly referred to "mistletoe from Africa" are used by communities of Cameroon for their numerous therapeutic virtues. The study examined the local various uses of Loranthaceae species in Diamare plain of Cameroon. Participatory rural appraisal method was used with 130 persons, namely traditional healers, breeders, farmers and foresters in order to identify the local uses of Loranthaceae species. We used itinerary botanical survey method in thirty-two (32) villages for the inventory of Loranthaceae species. In each village, two (02) itineraries (1000 m x $20 \mathrm{~m}$ ) were realized on account of one itinerary in an agrosystem and one itinerary in a natural site. Results revealed five categories of uses of Loranthaceae: human traditional pharmacopoeia, fodder, magical use, ritual use and veterinary medicine. Knowledge of Loranthaceae uses was broadly influenced by age of respondents, traditional healers and people over 41 years old were the major libraries of knowledge on Loranthaceae. Human traditional pharmacopoeia (96.92\%) and magical use (82.30\%) were the most important categories of uses. Nine Loranthaceae species were inventoried in natural and agrosystem sites, namely Agelanthus dodoneifolius (DC.) Polh. \& Wiens, Tapinanthus globiferus (A. Rich.) Tiegh., T. oleifolius (J.C.Wendl.), T. ophiodes (Sprague) Danser and T. voltensis Van Tiegh. ex Balle, Phragmanthera sp., Tapinanthus sp1., Tapinanthus sp2. and Tapinanthus sp3. . The most parasitized species with high rate of parasitism and vulnerability were Ziziphus mauritiana Lam. (58.33\%; 6.98\%), Acacia albida Del. (45.03\%; 13.97\%), Azadirachta indica A. Juss. (39.05\%; 18.03\%), Psidium guajava L. (29.62\%; 5.10\%) and Citrus limon (L.) Burm. f. (26.31\%; 6.36\%). Rate of parasitism and rate of vulnerability were positively but weakly correlated (Kendall, $\mathrm{r}=0.09$ ).
\end{abstract}

Keywords: Loranthaceae, Parasitism, Host, Natural Site, Agrosystem

\begin{abstract}
Introduction
African forests are a huge reservoir of biological diversity and their ecological functions are essential for humanity. Forest formations play an important role in meeting many of the basic needs of local populations. They provide wood and energy and help to cover the nutritional needs of various social groups. Likewise, they represent the main source of medicinal products in rural areas and participate in local and national economies (IPGRI, 1999). Thus, the medicinal and nutritional nature of these plant resources places them at the heart of any human activity requiring clear conservation. Unfortunately, this conservation is destroyed by the attack of plants of the Loranthaceae family (Bright and Okusanya, 1998; Ayuba, 2000; Bako et al., 2001; Wahab et al., 2010). Loranthaceae, designated under the common term of "African mistletoe", are phanerogams, chlorophyllian hemiparasites or
\end{abstract}

epiphytes which, implanted on the aerial parts of their hosts, are responsible for economic, ecological, morphogenetic and technological damage variable according to the cultures or parasitized woody species (Sallé et al., 1998). These hemiparasites are plants that have lost their autonomy in accessing nutrient resources during their evolution and have become dependent on their hosts. They attach themselves to their hosts through a specific organ called a haustorium or sucker which establishes contact with its host at the level of xylemic connections (Sallé et al., op. cit.). Several studies carried out on Loranthaceae in Africa showed that they drastically reduce the productivity of their hosts (Boussim, 2002; Edagbo et al., 2013; Massako et al., 2013). The latter represent a real scourge against which a proactive fight is essential, given the extent of the damage. Faced with this situation, Boussim et Medah (2004)

This article is published under the terms of the Creative Commons Attribution License 4.0 Author(s) retain the copyright of this article. Publication rights with Alkhaer Publications. Published at: http://www.ijsciences.com/pub/issue/2020-08/

DOI: 10.18483/ijSci.2350; Online ISSN: 2305-3925; Print ISSN: 2410-4477 
tested several methods of combating these hemiparasites in Burkina Faso. The most applicable methods are mechanical control, biological control and the selection of resistant varieties. Sallé and Aber (1986) mentionned that such a struggle necessarily requires better knowledge of the geographic distribution and the biology of the target organisms. However, the systematic eradication of Loranthaceae would not be very reasonable since these plants are in great demand by the populations especially for their therapeutic potentials (Jiofack et al., 2010; Ogunmefun et al., 2013; O'neill et Rana, 2016). This makes these plants an asset for the development of the African pharmacopoeia, so that their large-scale use as a biological control method has been recommended (Jiofack et al., 2010). From one region to another, their use in therapy manifests itself either in isolation, or according to an appropriate or specific host, or finally in combination with other drugs or solvents (Jiofack et al., 2009).

The importance of Loranthaceae in plant resources has been assessed by several authors, notably in Nepal, Cameroon and Nigeria (Dibong et al., 2009; Ongunmefun et al ., 2015; O'neill et Rana, 2016). It emerges from all their work that the Loranthaceae are used not only in traditional medicine but also for fodder, human food, the manufacture of ritual objects and as material for capturing birds. The major problem is the fight against poverty and undernourishment, in connection with an explosive demography which is at the origin of the disappearance of forest recruits. This situation is at the origin of agroforestry plantations and house gardens, in which fruit trees are very often attacked by numerous phytoparasites. The latters are sometimes underestimated by the peasants, although they cause a lot of damage to their crops. However, Loranthaceae appear to be a panacea for the evils which weigh on the population because of its therapeutic and fodder virtues. In Cameroon, some surveys were conducted on socio-economic importance of the Loranthaceae and the parasitism in equatorial zone (Dibong et al. 2008; 2009; Feguem, 2011; Azo'o et al., 2013). Studies in the sudano-sahelian zone on Loranthaceae are still to be carried out. The survey aims at examining the local uses of Loranthaceae species and their potential existing in sudano-sahelian zone of Cameroon in view of their sustainable management.

\section{Materials and methods \\ Study site}

The study was carried out in the Far- North Region of Cameroon, in the Diamare plain including MayoKani and Diamare Divisions. These Divisions cover a total area of $6450 \mathrm{~km}^{2}$ and a population of 768
603 inhabitants (MINATD, 2010). It is located between $10^{\circ} 0^{\prime} \mathrm{N}$ to $10^{\circ} 48^{\prime} \mathrm{N}$ and $14^{\circ} 0^{\prime} \mathrm{E}$ to $14^{\circ} 48^{\prime}$ E (Fig. 1).The climate is of the Sudano-sahelian zone and is characterized by two seasons, a long dry season (8 to 9 months) spanning from October to May and a short rainy season (3 to 4 months) from June to September (Fotsing, 2009). Very high temperatures reaching $45^{\circ} \mathrm{C}$ under shade and a very dry atmosphere are experienced from March to June (MINATD, 2010). Rainfall varies between 600 and $900 \mathrm{~mm} /$ year, with maximum rainfall mostly between July and August (Djibrilla, 2016). Hydrography is made up of temporal flowing rivers (Mayos) which dry up at the end of the rainy season. The main soil types encountered are vertisols, hardés, sandy soils, rocky soils in mountain areas, and silty soils favorable to market gardening (FAO, 2011).

The vegetation is characterized by a shrub steppe of the Sudano-Sahelian type. The most popular plant species are: Adansonia digitata, Khaya senegalensis, Tamarindus indica, Acacia albida, Acacia spp., Ziziphus mauritiana and Ficus spp. Most of these plants are used for livestock feed (Wafo, 2008). Other African mistletoe and Acacia albida are appreciated for their leaves serving as fodders and their fertilizing roots. Fertile soils are indicated by the presence of Acacia albida (Djibrilla, 2016). The wildlife is poor and is endangered due to the lack of a conducive environment for their development. Some species are mostly located in the mountains, and include rodents (mice, rats, damans, squirrels, hares); reptiles (lambs, lizards, snakes); locusts and caterpillars; sparrows; hyenas; panthers and wild cats; monkeys (IPCC, 2007). Most of the people rely on agriculture, livestock and forest resources to meet their basic needs. 
Local Uses and Parasitism of Loranthaceae in Sudano-Sahelian Zone of Cameroon: Case of Diamare Plain in Far North Region

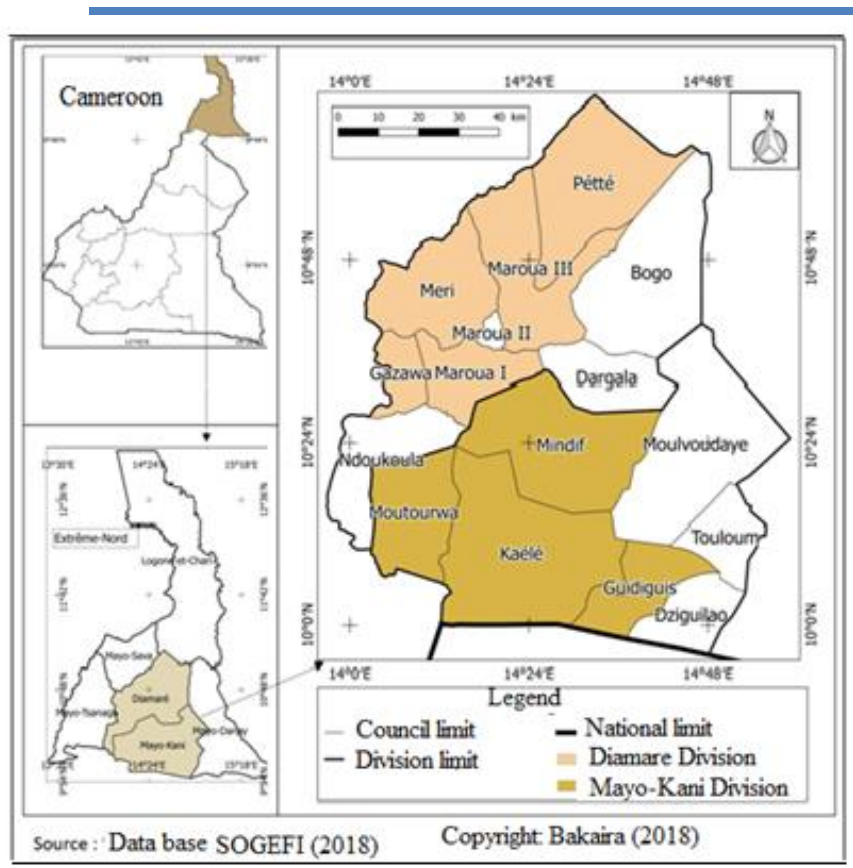

Figure 1: Map of location of study site.

\section{Data collection \\ Determination of local uses of Loranthaceae in Diamare plain}

The uses of Loranthaceae were determined through ethnobotanical surveys with the local populations in thirty-two (32) villages. Participatory rural appraisal method (Shillington, 2002) was performed with 130 persons aged from 20 to 88 years, $104(81 \%)$ men and $26(19 \%)$ women. The target groups were constituted of traditional healers (23), pastoralists (57), farmers and/or foresters (50). Traditional rulers were highly involved in the choice of the actors. With these target populations, semi-structured (individual) and structured interviews (focus group discussions) were realized concerning the knowledge of Loranthaceae and their hosts, and the indigenous uses made of these hemiparasites (Grangé et Libart, 1992). During the focus discussions, each member was free to comment, to criticize or to speculate on the views expressed by the previous speakers.

Inventory of Loranthaceae and their hosts in agrosystems and natural sites

Loranthaceae and their host species were identified using the itinerary botanical survey method (Konadio, 2007) in the areas indicated by the respondents in thirty-two (32) villages. The villages were chosen on the basis of the presence of agrosystems and natural sites in the localities. In each village, a planted site or orchard and a natural site were sampled, and an itinerary botanical survey $(1000 \mathrm{~m} \times 20 \mathrm{~m})$ was realized in each plant formation. In the various itineraries, all parasitized trees were censused and identified, and the number of tufts was counted. Loranthaceae specimens were collected, identified and/or confirmed with the help of volumes on Loranthaceae in "Flora of Cameroon" (Balle, 1982) and in "Trees, shrubs and lianas of dry areas in West Africa (Arbonnier, 2000).

Data processing and analysis

For each plant tree, the rate of parasitism was calculated (Massako et al., 2013):

$\mathrm{RP}=\frac{\text { Number of parasitized individuals }}{\text { Total number of individuals }} \times 100$

Where RP is the rate of parasitism.

The rate of vulnerability was calculated for each species following the formula (Massako et al., 2013):

RV

$=\frac{\text { Number of tufts of parasites on an individual }}{\text { Total number of tufts on all individuals }} \times 100$

Where RV is the rate of vulnerability.

The variation of parasitism between natural sites and agrosystems was realized by using Analysis of Variance (ANOVA) at the level of 0.05 .

All the statistical analyses were performed with Origin 6.0 Sofware.

\section{Results}

Local uses of Loranthaceae in Diamare plain

Local populations of Diamare plain are unanimous on the therapeutic virtues of Loranthaceae species. They are involved in five (05) categories of uses: human traditional pharmacopoeia, veterinary medicine, fodder, ritual and mystical uses. Human traditional pharmacopoeia and magic were the most important categories of uses $(96.92 \%$ and $82.30 \%$ respectively). In terms of traditional human medicine, sterility, painful periods and mental disorders were recognized by all traditional healers as ailments treated by Loranthaceae species. The other diseases treated by the hemiparasites were malaria, darter and ringworm. For magical uses, traditional healers and the elders enumerated luck, magic spells, madness and bewitchment. Veterinary medicine was less used according to respondents, with a rate of $1.53 \%$ (Figure 2). At the level of 0.05 , the means were significantly different (ANOVA, $\mathrm{p}<0.05$ ). This difference can be explained by the diversity of ethnicities, habits and customs in the Diamare plain. For example, in the locality of Mindif in Mayo-Kani division, ritual use was more important than that of Diamare division whereas human traditional pharmacopoeia and magic were similar in all the localities. 


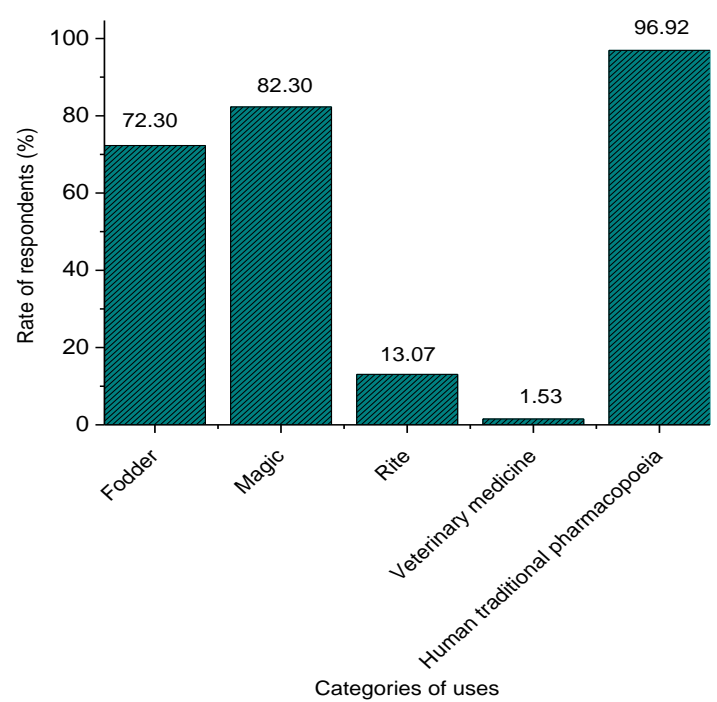

Figure 2: Rate of representation of categories of uses according to respondents.

Considering the knowledge of Loranthaceae according to age classes, the persons aged between 41-60 and 61 and more were holders of all uses of Loranthaceae (Figure 3). Individuals included between 20 and 40 ages did not master all the uses of these hemiparasites, namely the ritual use. In fact, they are not involved in the receipts based on mistletoes. There was a significant difference between the tranches of ages (ANOVA, $p \leq 0.05$ ).

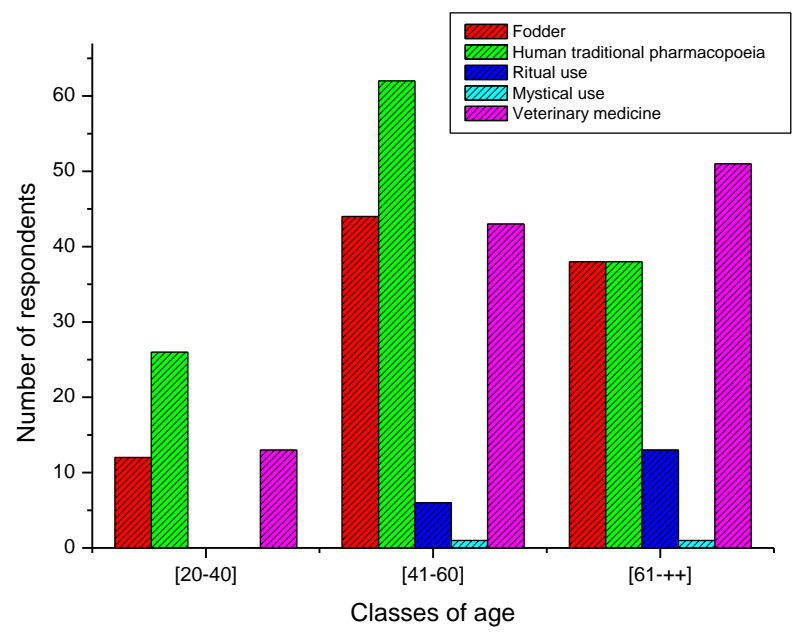

Figure 3: Level of knowledge of Loranthaceae use according to classes of age.

\section{Knowledge of Loranthaceae by ethnic groups in Diamare plain}

In the Diamare plain, Loranthaceae are named according to the host species and each ethnic group has his own designation (Table 1). The various designations are also in relation with the capacity of destruction of the Loranthaceae species. Seven (07) ethnic groups were identified in the study site, namely Toupouri, Moundang, Guiziga, Massa, Moufou, Peuhl and Sirata.

Table 1: Designations of Loranthaceae by ethnic groups in Diamare plain.

\begin{tabular}{lc}
\hline Ethnic groups & Designations of Loranthaceae \\
\hline Toupouri & Fiyeng \\
Moundang & Keebbaah \\
Guiziga & Mourloum \\
Massa & Vianga \\
Moufou & Mehenek \\
Peuhl & Yeotere \\
Sirata & Boroungo \\
\hline
\end{tabular}

Diversity of Loranthaceae species, host species and parasitism

Nine (09) useful species of Loranthaceae were inventoried in the agrosystems and natural sites of Diamare plain. They were: Agelanthus dodoneifolius (DC.) Polh. \& Wiens, Tapinanthus globiferus (A. Rich.) Tiegh., T. oleifolius (J.C.Wendl.), T. ophiodes (Sprague) Danser and $T$. voltensis Van Tiegh. ex Balle. The four (04) other species were determined at the level of genus, namely Phragmanthera sp., Tapinanthus sp1., Tapinanthus sp2. and Tapinanthus sp3. They infested both native and exotic species (Table 2).

In total, twenty-five (25) potential host species were censused. Most of the parasitized individuals carried either tufts of Agelanthus dodoneifolius or Tapinanthus globiferus or the tufts of both species associated. They represented $69.42 \%$ of the total rate of parasitism in natural sites and agrosystems. In natural sites, the most parasitized species with high rate of vulnerability were: Ziziphus mauritiana Lam. (58.33\%; 6.98\%); Acacia hockii De Willd. (46.72\%; 5.73\%); Acacia albida Del. (45.03\%; $13.97 \%)$. In agrosystem sites, Azadirachta indica A. Juss. (39.05\%; 18.03\%); Psidium guajava L. (29.62\%; 5.10\%) and Citrus limon (L.) Burm. f. $(26.31 \% ; 6.36 \%)$ represented the most parasitized species.

The average rate of parasitism was $29.07 \%$ for 1701 individuals inventoried in both natural and 
Local Uses and Parasitism of Loranthaceae in Sudano-Sahelian Zone of Cameroon: Case of Diamare Plain in Far North Region

agrosystem sites. Three (03) species did not host any parasitic plant, namely Acacia sieberiana DC., Eucalyptus camaldulensis Dehnh. and Mangifera indica L. The average rate of vulnerability of parasitized individuals was $4.48 \%$. Azadirachta indica A. Juss. (RV = 18.03\%), Acacia albida Del.
$(\mathrm{RV}=13.97 \%)$ and Ziziphus mauritiana Lam. represented the most vulnerable hosts in the site study. Rate of parasitism and rate of vulnerability were positively but weakly correlated (Kendall, $r=$ $0.09)$.

Table 2: Hosts, Loranthaceae species and parasitism.

\begin{tabular}{|c|c|c|c|c|c|c|}
\hline \multirow[t]{2}{*}{ Host species } & \multirow{2}{*}{$\begin{array}{l}\text { Number of } \\
\text { individuals }\end{array}$} & \multirow[t]{2}{*}{ Infested individuals } & \multirow[t]{2}{*}{ Parasitic species } & \multirow[t]{2}{*}{ Number of tufts } & \multicolumn{2}{|c|}{ Parasitism } \\
\hline & & & & & RP (\%) & RV (\%) \\
\hline Acacia albida Del. & $\begin{array}{l}119 \\
32\end{array}$ & $\begin{array}{l}56 \\
12 \\
\end{array}$ & $\begin{array}{l}\text { Agelanthus dodoneifolins (DC.) Polh. \& Wiens } \\
\text { Tapinanthus globiferis (A. Rich.) Tiegh. }\end{array}$ & $\begin{array}{l}78 \\
56 \\
\end{array}$ & 45.03 & 13.97 \\
\hline Acacia nilotica (L.) Wild ex Del. & 244 & 87 & $\begin{array}{l}\text { Agelanthus dodoneifolins (DC.) Polh. \& Wiens } \\
\text { Tapinanthus globiferus (A. Rich.) Tiegh. } \\
\text { Tapinanthus ophiodes (Sprague) Danser }\end{array}$ & $\begin{array}{l}56 \\
29 \\
10\end{array}$ & 35.65 & 9.90 \\
\hline Acacia hockï De Willd. & 107 & 50 & $\begin{array}{l}\text { Agelanthus dodoneifolius (DC.) Polh. \& Wiens } \\
\text { Tapinanthus globiferus (A. Rich.) Tiegh. } \\
\text { Tapinanthus ophiodes (Sprague) Danser }\end{array}$ & $\begin{array}{l}30 \\
20 \\
05\end{array}$ & 46.72 & 5.73 \\
\hline Acacia seyal Del. & 30 & 10 & $\begin{array}{l}\text { Agelanthus dodoneifolins (DC.) Polh. \& Wiens } \\
\text { Tapinanthus globiferis (A. Rich.) Tiegh. }\end{array}$ & $\begin{array}{l}20 \\
05 \\
\end{array}$ & 33.33 & 2.60 \\
\hline Acacia sieberiana DC. & 21 & - & & 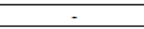 & & 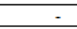 \\
\hline Anogeissus leiocarpus (DC.) Guill. \& Perr. & 96 & 33 & $\begin{array}{l}\text { Agelanthins dodoneifolins (DC.) Polh. \& Wiens } \\
\text { Phragmanthera sp. } \\
\text { Tapinanthus globiferus (A. Rich.) Tiegh. }\end{array}$ & $\begin{array}{l}68 \\
03 \\
12 \\
\end{array}$ & 34.37 & 8.65 \\
\hline Azadirachta indica A. Juss. & 274 & 107 & Agelanthus dodoneifolins (DC.) Polh. \& Wiens & 173 & 39.05 & 18.03 \\
\hline Balanites aegyptiaca $\mathrm{L}$. & 157 & 15 & Tapinanthus globiferils (A. Rich.) Tiegh. & 25 & 09.55 & 2.60 \\
\hline Calotropis procera (Ait) Ait. f. & 24 & 01 & Tapinanthus globiferus (A. Rich.) Tiegh. & 02 & 04.16 & 0.20 \\
\hline Boswellia dakielii Hutch. & 10 & 01 & $\begin{array}{l}\text { Tapinanthus sp1. } \\
\text { Tapinanthus sp2. }\end{array}$ & $\begin{array}{l}03 \\
01\end{array}$ & 10 & 0.41 \\
\hline Citrus limon (L.) Burm. f. & 76 & 20 & Agelanthus dodoneifolins (DC.) Polh. \& Wiens & 61 & 26.31 & 6.36 \\
\hline Delonix regia (Boj.) Raf. & 35 & 14 & Tapinanthus globiferils (A. Rich.) Tiegh. & 26 & 40 & 2.71 \\
\hline Grewia bicolor Juss. & 20 & 01 & Tapinanthus sp3. & 04 & 05 & 0.41 \\
\hline Khaya senegalensis (DC.) A. Juss. & 25 & 07 & $\begin{array}{l}\text { Agelanthus dodoneifolints (DC.) Polh. \& Wiens } \\
\text { Tapinanthus globiferus(A. Rich.) Tiegh. }\end{array}$ & $\begin{array}{l}03 \\
03\end{array}$ & 28 & 0.62 \\
\hline Pithecellobium dulce (Roxb.) Benth. & 05 & $\begin{array}{l}01 \\
01\end{array}$ & $\begin{array}{l}\text { Agelanthus dodoneifolius (DC.) Poll. \& Wiens } \\
\text { Tapinanthus globiferus(A. Rich.) Tiegh. }\end{array}$ & $\begin{array}{l}02 \\
01\end{array}$ & 40 & 0.31 \\
\hline & & $\begin{array}{l}05 \\
02\end{array}$ & $\begin{array}{l}\text { Agelanthus dodoneifolius (DC.) Polh. \& Wiens } \\
\text { Tapinanthus globiferus (A. Rich.) Tiegh. }\end{array}$ & $\begin{array}{l}22 \\
18\end{array}$ & 29.62 & 5.10 \\
\hline $\begin{array}{l}\text { Psidium guajava } \mathrm{L} . \\
\text { Serna singueana (Del.) Lock }\end{array}$ & $\frac{27}{34}$ & $\frac{01}{16}$ & $\begin{array}{l}\text { Tapinanthus ophiodes (Sprague) Danser } \\
\text { Tapinanthus globiferus (A. Rich.) Tiegh. }\end{array}$ & $\frac{09}{28}$ & 47.05 & 3.00 \\
\hline Terminalia macroptera Guill. \& Perr. & 143 & $\begin{array}{l}10 \\
08\end{array}$ & $\begin{array}{l}\text { Agelanthus dodoneifolins (DC.) Polh \& Wiens } \\
\text { Tapinanthus globiferis (A. Rich.) Tiegh. }\end{array}$ & $\begin{array}{l}20 \\
12 \\
\end{array}$ & 12.58 & 3.33 \\
\hline Eucahptus camaldulensis Dehnh. & 26 & - & - & - & - & - \\
\hline $\begin{array}{l}\text { Diospyros mespiliformis Hochst. ex A. } \\
\text { Rich. }\end{array}$ & 15 & 01 & Tapinanthus ophiodes (Sprague) Danser & 08 & 06.66 & 0.83 \\
\hline Ficus thonningii Blume & 34 & 10 & Agelanthus dodoneifolins (DC.) Polh. \& Wiens & 20 & 29.41 & 2.08 \\
\hline $\begin{array}{l}\text { Lannea fruticosa (Hochst. ex A. Rich.) } \\
\text { Engl. }\end{array}$ & 40 & $\begin{array}{l}01 \\
10\end{array}$ & $\begin{array}{l}\text { Tapinanthus voltensis Van Tiegh. ex Balle. } \\
\text { Tapinanthus globiferus (A. Rich.) Tiegh. }\end{array}$ & $\begin{array}{l}01 \\
25\end{array}$ & 27.5 & 2.71 \\
\hline Mangifera indica $\mathrm{L}$. & 51 & - & & - & - & - \\
\hline Tamarindis indica $\mathrm{L}$. & 32 & 10 & Agelanthus dodoneifolins (DC.) Polh. \& Wiens & 20 & 31.25 & 2.08 \\
\hline Ziziphus mauritiana Lam. & 24 & 14 & Tapinanthus globifferus (A. Rich.) Tiegh. & 67 & 58.33 & 6.98 \\
\hline
\end{tabular}

\section{Discussion}

Local uses and knowledge of Loranthaceae in Diamare plain

Loranthaceae species were involved in five (05) categories of uses in the Diamare plain, namely human traditional pharmacopoeia, veterinary medicine, fodder, ritual and mystical uses. This diversity of categories of uses is similar to that was found in Nepal where Loranthaceae were used in traditional medicine, as fodder, food, for ritual purpose and as bird catching equipment (O'neill et Rana, 2016). On the other hand, this diversity of categories of uses of Loranthaceae was higher in the northern part of Benin. A total number of six (06) categories of uses was indicated, namely traditional medicine, veterinary medicine, magic, food, fodder and cosmetics (Ahamide et al., 2017).

The preponderance of medicinal uses of Loranthaceae revealed by our investigations is well recognized around the world (Takem et al., 2014) and can be explained by the active ingredients contained in these hemiparasites. Among the diseases treated with Loranthaceae species, malaria, blood pressure and sterility were regularly cited. The use of Loranthaceae in the treatment of some of these diseases had already been reported (Dibong et al., 2009) or even scientifically justified by other authors. Indeed, the antimalarial properties of Agelanthus dodoneifolius are linked to the presence of saponins, anthraquinones, tannins, terpenes, phenols, reducing sugar and sterols (Builders et al., 2012). The antipyretic activity of the aqueous extract of Phragmanthera capitata had been proven and therefore supports the use of this plant in the traditional treatment of fever in Cameroon (Takem et al., 2014). The work of Aliyu et al. (2014) revealed the anticonvulsant effect of Globimetula braunii to justify its involvement in the treatment of epilepsy in traditional medicine in Nigeria. The vasodilating activity of the aqueous extract of Agelanthus dodoneifolius (Ouédraogo et al., 2005) helps to support the involvement of Loranthaceae in the treatment of blood pressure disorders cardiovascular accident. In addition, the leaves of Tapinanthus spp. contain polyphenols with hypotensive properties and active substances such as lectins and viscotoxins, which have an 
immunostimulatory action (Tsabang et al., 2012).

Magic effects had been reported in interviews with traditional healers and the elders, including luck, magic spells, trading, madness and bewitchment. These results are similar to those reported by Adjanohoun (2001) on magic plants, where he reported that Tapinanthus spp. are used in cases of exorcism and bad luck. He added that if someone uses Loranthaceae species growing on Calotropis procera, he will be protected from all diseases, including viral diseases. In our study site, traditional healers indicated that any species of mistletoes found on Calotropis procera and Mangifera indica would give some sort of power over mystical attacks and would bring good luck by chasing away negative waves. These statements corroborate those of Jiofack et al. (2010) who evokes the magic power of parasitic plants of Mangifera indica and its implication in the treatment of patients suffering from congenital and hereditary diseases.

The solicitation of Loranthaceae for fodder and veterinary medicine in our study area was already mentioned by Ahamidé et al. (2017) and Houènon (2012). Hemiparasites are well used against certain animal pathologies. Our results corroborate those of several authors who had reported the involvement of Loranthaceae in the treatment of convulsion and foot-and-mouth disease in Benin (Dassou et al., 2014), the treatment of bovine pasteurellosis, footand-mouth disease, convulsion (Ahamidé et al., 2017) and the efficacy of these plants in the treatment of African trypanosomiasis in Nigeria (Edagbo et al., 2013).

Knowledge of Loranthaceae was influenced by the age of respondents. Our results showed that people over 41 years old constituted the major poles of possession of knowledge of uses of Loranthaceae and must therefore be taken into account in priority in the different strategies for valuing these hemiparasites. Indeed, the high level of knowledge of the elderly can be explained by the experiences accumulated by them in an area where endogenous knowledge on the uses of Loranthaceae is gradually delivered. The strong knowledge that traditional healers and breeders have of the Loranthaceae is said to be due to their strong direct dependence on plant resources. However, this strong dependence of the respondents on Loranthaceae coupled with an indiscriminate use of parasitic species in the study area constitute a threat to the survival of certain Loranthaceae species with high parasitic specificity. This observation was made in Brazil concerning the influence of age on the knowledge of medicinal plants in general (De Almeida et al., 2012). The results of the surveys have also shown that traditional therapists succeed in attributing a local name to the Loranthaceae, according to their ethnic groups. The local name assignment to the latter indicates that they know the Loranthaceae (Amon, 2006). This confirms the remarks that local populations do not name plants they do not use (Adjanohoun, 2001).

\section{Loranthaceae, host species and parasitism}

Native and exotic trees of Diamare plain were attacked by nine (09) species of Loranthaceae Family. This number is more important than that of Amon et al. (2017) and Dibong et al. (2008) who found seven (07) species and eight (08) species respectively in South-Comoé region of Ivory-Coast and Littoral region in Cameroon. Amongst the nine Loranthaceae species, two of them namely Agelanthus dodoneifolius and Tapinanthus globiferus represented $69.42 \%$ of the total rate of parasitism in natural sites and agrosystems. It could be seen that these two species are not specific to a host plant or a locality. Host species like Mangifera indica and Calotropis procera were widely cited by local populations because of the important role of the mistletoes they could host. But in the field, only one individual of Calotropis procera was attacked by Tapinanthus globiferus and no individual of Mangifera indica was parasitized. It could be observed that Calotropis procera is not very sensitive to hemiparasites and Mangifera indica is resistant to parasitic plants. Calotropis procera was found among the least sensitive host species in Benin (Houenon et al., 2012) and Mangifera indica was said to be resistant to parasitic plants (Dibong et al., 2008). These results corroborate those of Dibong et al. (2008) which presented Mangifera indica as a resistant species to the parasitism of Loranthaceae and differ from those of Feguem (2011) and Amon et al. (2015). These authors showed that Mangifera indica was parasitized in the North-West region of Cameroon and SouthComoé region of Ivory-Coast respectively. These results make us think that to date, there are certainly no resistant species to hemiparasites, but rather species not yet discovered not parasitized by Loranthaceae species.

\section{Conclusion}

Ethnobotanical survey, carried out in Diamare plain of the sudano-sahelian zone of Cameroon, showed that nine Loranthaceae species were used by local populations. They were involved in five categories of uses, namely human traditional pharmacopoeia, veterinary medicine, fodder, ritual and mystical uses. Human traditional pharmacopoeia (96.92\%) and magical use $(82.30 \%)$ were the most important categories of uses. All the seven ethnic groups 
censused in the study site knew perfectly Loranthaceae species and persons aged above 41 years old were holders of all uses of these parasitic plants. The nine useful Loranthaceae species inventoried both in agrosystem and natural sites were: Agelanthus dodoneifolius (DC.) Polh. \& Wiens, Tapinanthus globiferus (A. Rich.) Tiegh., T. oleifolius (J.C.Wendl.), T. ophiodes (Sprague) Danser and T. voltensis Van Tiegh. ex Balle, Phragmanthera sp., Tapinanthus sp1., Tapinanthus sp2. and Tapinanthus sp3. Twenty-five potential host species were inventoried, and the most parasitized species with high rate of parasitim and vulnerability were Ziziphus mauritiana Lam. (58.33\%; 6.98\%), Acacia hockii De Willd. (46.72\%; 5.73\%), Acacia albida Del. (45.03\%; $13.97 \%$ ), Azadirachta indica A. Juss. (39.05\%; $18.03 \%)$, Psidium guajava L. (29.62\%; 5.10\%) and Citrus limon (L.) Burm. f. (26.31\%; 6.36\%). The popularization of knowledge on the uses of Loranthaceae and the collaboration between local users and Botanists will contribute to the promotion and sustainable management of these parasitic plants.

\section{Acknowledgements}

The authors thank the IDEA WILD for the support given to Souare Konsala through a small grant. The material equipment permitted to realize the project. They also thank the populations of Diamare plain for their collaboration.

\section{References}

1. Adjanohoun, E. J. (2001): La médecine traditionnelle au Benin: recensement des savoir-faire traditionnel. Extrait du rapport Centrebat. Cbdd. Revue de Médecine et pharmacopées Africaines, 15: 103-111.

2. Ahamidé, I. D., Tossou, M., Dassou, H., Yedomonhan, H., Houènon, J. et Akoegninou, A. (2017) : Usages des plantes parasites de la famille des Loranthaceae et variation du niveau de leurs connaissances au Nord-Benin : implication pour la gestion durable des hémiparasites. Afrique Science, 13: 222-235.

3. Aliyu, M. M., Musa, A. I., Kamal, M. J. and Mohammed, M. G. (2014): Phytochemical screening and anticonvulsant studies of ethyl acetate fraction of Globimetula braunii on laboratory animals. Asian Pacific Journal of Tropical Biomedicine, 4(4): 285-289. 10.12980/APJTB.4.2014C 925 .

4. Amon, A. D. E. (2006): Les plantes vasculaires parasites de la famille des Loranthaceae rencontrées dans le Département de Grand-Bassam, au Sud de la Côte d'Ivoire. Mémoire de D.E.A. de Botanique, Université Cocody, U.F.R. Biosciences. Abidjan, Côte d'Ivoire. 57 p.

5. Amon, A. D. E, Soro, D. and Traoré, D. (2015) : Evaluation de l'infestation des Loranthacées sur les ligneux des agroécosystèmes de la région du SudComoé (Côte d'Ivoire). International Journal of Biological and Chemical Sciences, 9(4): 1822-1834. DOI: http://dx.doi.org/10.4314/ijbcs.v9i4.8.

6. Amon, A. D. E., Seguena, F., Soro, K., Soro, D. and N'guessan, K. (2017): Ethnobotany study of Loranthaceae, hemiparasitic plants used in traditional medicine by populations in the Sud-Comoé region (Côte d'Ivoire).
Journal of Medicinal Plant Studies, 5(5): 217-224.

7. Arbonnier, M. (2000): Arbres, arbustes et lianes des zones sèches d'Afrique de l'Ouest. MNHN. 345 p.

8. Ayuba, I. (2000) : A Survey of Occurrence, Distribution and Effects of African Mistletoe (Tapinanthus spp.) on Parkia biglobosa (Jacq.) and Butryospermum Paradoxum (Gaertn. f.) Hepper in Yauri Local Government Area of Kebbi State. M.Sc. Dissertation, UDUS Sokoto State.

9. Azo'o, J., Tchatat, M., Mony, R. et Dibong, S. (2013) : Parasitisme et ethnobotanique des Loranthaceae à Lokomo (Est-Cameroun). Journal of Animal and Plant Sciences, 19(2): 343-345. http://www.m.elewa.org/JAPS; ISSN 2071-7024

10. Bako, S.P., Onwuchekwa, B. N., Bako, L.S.P. and Iortsuun, D. N. (2001): Physiology of the African Mistletoe (Tapinanthus dodoneifolius (DC.) Danser and its influence on the metabolism of two hosts (Albizia lebbeck Benth and Citrus sinensis L.). Nigerian Journal of Agriculture and Environment, 2: 1081-1092.

11. 11. Balle, S. (1982): Loranthacées. In Flore $d u$ Cameroun (Vol. 23), Satabié B, Leroy JF (Eds). Délégation Générale à la Recherche Scientifique et Technique : Yaoundé, Cameroun, $82 \mathrm{p}$.

12. Boussim, I. J. (2002) : Les phanérogames parasites du Burkina-Faso : inventaire, taxonomie, écologie et quelques aspects de leur biologie. Cas particulier des Loranthaceae parasites du karité. Thèse de Doctorat d'Etat de Université de Ouagadougou, Ouagadougou. 285 p.

13. Boussim, I. J. and Medah, N. (2004): Méthodes de lutte contre les Loranthaceae. Homme, plantes et environnement au Sahel occidental, 19 : 127-142.

14. Bright, E.O. et Okusanya, B. A. (1998): Infestation of economic plants in Badeggi by Tapinanthus dodoneifolius (D.C) Danser and T. globiferus (A. Rich) Van Tiegh. Nigerian Journal of Weed Science, 11 : 51-56.

15. Builders, M. I., Uguru, M. O. and Aguiyi, C. (2012): Antiplasmodial potential of the African mistletoe: Agelanthus dodoneifolius Polh and Wiens. Indian Journal of Pharmaceutical Sciences, 74(3): 223-229. DOI: 10.4103/0250-474X.106064.

16. Dassou, H. G., Ogni, C. A., Yedomonhan, H., Adomou, A. C., Tossou, M., Dougnon, J. T., Akoegninou, A. (2014) : Diversité, usages vétérinaires et vulnérabilité des plantes médicinales au Nord-Bénin. International Journal of Biological and Chemical Sciences, 8: 189-210. DOI: $10.4314 /$ ijbcs.v8i1.18.

17. De Almeida, C. F., Silva, M., De Melo, J., De Medeiros, De Sousa, T., De Almeida, A., De Amorim, E. (2012) : Intracultural Variation in the Knowledge of Medicinal Plants in an Urban-Rural Community in the Atlantic Forest from Northeastern Brazil. Evidence - Based, Complementary and Alternative Medicine, ID 679373, 15 p. https://doi.org/10.1155/2012/679373.

18. Dibong SD, Din N, Priso RJ, Taffouo VD, Fankem H, Salle G, Amougou A. 2008. Parasitism of host trees by the Loranthaceae in the region of Douala Cameroon. African Journal of Environmental Science and Technology, 2(11): 371 -378.

19. Dibong, S. D., Din, N., Priso, R. J., Taffouo, V. D., Fankem, H., Sallé, G., Missoup, A. D., Boussim, I. J. and Amougou, A. (2009): An Assessment on the Uses of Loranthaceae in Ethnopharmacology in Cameroun: a case study made in Logbessou, North of Douala. Journal of Medicine al Plants Research, 3(8): 592-595. http://www.academicjournals.org/JMPR.

20. Djibrilla, M. (2016): Etude de la vulnérabilité de la biodiversité végétale ligneuse dans la zone soudanosahélienne du Cameroun: cas du Département du Mayo-Kani (Canton de Lara). Mémoire de Master en Biologie des Organismes Végétaux, Université de Ngaoundéré, $80 \mathrm{p}$.

21. Edagbo, D. E., Ighere, D. A., Michael, C. (2013): Mistletoe (Tapinanthus bangwensis) on the Conservation Status and 
Productivity of Irvingia gabonensis in Moor Plantation Area of Ibadan, Nigeria. Greener Journal of Agricultural Sciences, 3(10): 743-747. http://www.gjournals.org.

22. FAO (2011) : Les forêts au service de la nutrition et de la sécurité alimentaire. Etude FAO, Rome. 10 p.

23. Feguem, M. (2011): Inventory of Loranthaceae parasite of fruiting trees in Tubah Sub-division, North-west Cameroon. DIPES II Thesis, University of Bamenda, Cameroon. $60 \mathrm{p}$.

24. Fotsing, E. (2009) : Small Savannah: Un système d'information pour l'analyse intégrée des changements d'utilisation de l'espace à l'Extrême-Nord, Cameroun. Thèse de Doctorat/ Ph.D, Université de Wageningen, Pays-Bas. 373 p.

25. Grangé, D. and Libart, L. (1992): Traitements Statistiques des Enquêtes. Eds Dunod. 254 p.

26. Houenon, J. G. (2012): Les Loranthaceae des Zones Guinéenne et Soudano-Guinéenne au Bénin et leur Impact sur les plantations Agrumicoles. Thèse de Doctorat de l'Université d'Abomey-Calavi, Abomey-Calavi. 133 p.

27. Houenon, J. G., Yedomonhan, H., Adomou, A. C., Tossou, M. G., Akoegninou, A. (2012): Les Loranthacées des zones guinéenne et soudano-guinéeene au Bénin et leurs hôtes. International Journal of Biological and Chemical Sciences, 6(4) : 1669-1686.DOI: http://dx.doi.org/10.4314/ijbcs.v6i4.24.

28. IPCC (2007) : Groupe de travail I du GIEC : Quatrième Rapport d'évaluation, Bilan 2007 des changements climatiques les bases scientifiques physiques, Résumé à l'intention des décideurs, $25 \mathrm{p}$.

29. IPGRI (1999) : Vers une approche régionale des ressources génétiques forestières en Afrique sub-saharienne. In: Premier atelier régional de formation sur la conservation et l'utilisation durable des ressources génétiques forestières en Afrique de l'Ouest, Afrique Centrale et de Madagascar, 299 Burkina-Faso.

30. Jiofack, T.R., Fokunang, C., Guedje, N., Kemeuze, V. A., Fongnzossie, E., Nkongmeneck, B., Mapongmetsem, P. M. et Tsabang, N. (2009): Ethnobotanical uses of some plants of two ethnoecological regions of Cameroun. African Journal of Pharmacy and Pharmacology, 3(13): 664-684. http://www.academicjournals.org/ajpp.

31. Jiofack, T. R., Dondjang, J., Smith, M. et Kemeuze, V. A. (2010) : Diversité et gestion durable des Loranthaceae dans les hautes terres de l'Ouest du Cameroun. Bois et forêts des tropiques, 303(1): 41-52. DOI: 10.19182/bft2010.303.a20449

32. Massako, F., Tchatat, M., Mony, R., Ladoh, Y. C. F., Dibong, S. D. (2013): Parasitisme de Dacryodes edulis par le genre Tapinanthus (Loranthaceae) et répartition de la
Myrmécofaune associée à Logbessou Plateau (Douala, Cameroun). Journal of Applied Biosciences, 68: 53365348. http://www.m.elewa.org/JABS/201 3/68/1.

33. MINADT (2010): Enquête agricole au Cameroun. Manuel d'instruction aux agents recenseurs. $45 \mathrm{p}$.

34. O'neill, A. R. et Rana, S. K. (2016): An ethnobotanical analysis of parasitic plants (Parijibi) in the Nepal Himalaya. Journal of Ethnobiology and Ethnomedicine, 12(14): 1-15. DOI: 10.1186/s13002-016-0086-y.

35. Ogunmefun, O. T., Fasola, T., Saba, A. et Oridupa, O. (2013): The ethnobotanical, Phytochemical and Mineral Analyses of Phragmanthera incana (Klotzsch), A Species of Mistletoe Growing on Three Plant Hosts in SouthWestern Nigeria. International Journal of Biomedical Sciences, 9(1): 33-40.

36. Ogunmefun, O. T., Olatunji, B. et Adarabioyo, M. (2015): Ethnomedicinal Survey on the Uses of Mistletoe in SouthWestern Nigeria. European Journal of Medicinal Plants, 8(4): 224- 230.

37. Ouédraogo, S., Traoré, A., Somé, N., Lompo, M., Guissou, I., Schott, C. and Bucher, B. (2005): Cardivascular properties of Tapinanthus dodoneifolius (DC.)Danser. African Journal of Traditional, Complementary and Alternative medicines, 2: 25-30.

38. Salle, G. et Aber, M. (1986): Les phanérogames parasites : biologie et stratégies de lutte. Bull. Soc. Bot. France, Lettre bot. 3, pp. 235-263.

39. Sallé, G, Tuquet, C., Raynal-Roques A. (1998): Biologie des phanérogames parasites. C. R. Soc. Biol., $192.36 \mathrm{p}$.

40. Takem, L. P., Abe, N. P. and Ogbonna, O. J. (2014): AntiPyretic and Analgesic Potentials of Aqueous Extract of Phragmanthera capitata S. Balle in Albino Rats. American Journal of Pharmacy and Pharmaceutical Sciences, 1(2): $37-43$.

41. Tsabang, N., Tsouh F. P. V., Yamthe, T. L. R., Noguema, B. , Bakarnga-Via, I., Nguepi, M. S. D., Nkongmeneck, B A., Boyomb, F. F. (2012): Ethnopharmacological survey of Annonaceae medicinal plants used to treat malaria in four areas of Cameroon. Journal of Ethnopharmacology, 139(2012): 171-180 doi:10.1016/j.jep.2011.10.035.

42. Wafo, G. (2008): Les aires protegées de l'ExtrêmeNord Cameroun entre politique de conservation et pratiques locales, Thèse Doctorat en Géographie Aménagement-Environnement, Université d'Orléans. 325 p.

43. Wahab, O. M., Ayodele, A. and Moody, J. (2010): Phytochemical Screening in some Nigerian Loranthaceae. Journal of Pharmacognosy and Phytotherapy, 2(5): 64-70. 